Cell Research(1995),5,187-195

\title{
Plant regeneration from protoplasts of hydroxyproline resistant cell line in Onobrychis viciaefolia
}

\author{
XU ZIQIN, JINGFEN JIA ${ }^{1}$ \\ Cell Biology Laboratory, Lanzhou University, Lanzhou \\ 730000, China.
}

\section{ABSTRACT}

An efficient protocol for plant regeneration from protoplasts of hydroxyproline(HYP)resistant cell line of Onobrychis viciaefolia was established. In SH medium supplemented with $1 \mathrm{mg} / \mathrm{L} \mathrm{2,4-dichlorophenoxy-acetic} \mathrm{acid} \mathrm{(2,}$ 4-D), $0.5 \mathrm{mg} / \mathrm{L}$ kinetin (KT) and $0.2 \mathrm{mg} / \mathrm{L}$ naphthalene acetic acid (NAA), the division frequency of protoplastderived cells reached up to over $60 \%$, and microcalli were obtained in 5-6 wk. Upon transferring them on agar solidified MS medium plus $2 \mathrm{mg} / \mathrm{L}$ indole-3-acetic acid (IAA), shoots were induced. After cultivating them on MS medium with or without IAA, roots were regenerated. Chromosome number of all protoplast-regenerated plants examined were normal $(2 \mathrm{n}=28)$. The protoplast-derived calli and plants grew vigorously on the medium containing $10 \mathrm{mmol} / \mathrm{L}$ HYP.

Key words: Sainfoin (Onobrychis viciaefolia), hydroxyproline resistant cell line, protoplast culture, plant regeneration.

\section{INTRODUCTION}

Sainfoin (Onobrychis viciaefolia Scop.) is a forage legume growing in arid area. It combines drought resistant and higher palatability with valuable protein and nonbloating properties. Such species is an ideal partner for somatic hybridization with other forage legume such as alfalfa[1]. Although plant regeneration from sainfoin protoplast has been reported[2-3], no genetic markers in this species could be used

1. Corresponding author 
Plant regeneration from sainfoin protoplasts

for identification of somatic hybrid cells.

A stable HYP resistant cell line of sainfoin has been selected in our laboratory[4]. The calli have been subcultured for 16 months on MS medium without hydroxyproline. The present work described the conditions for protoplast isolation, culture and plant regeneration from protoplasts of this selected HYP-resistant cell line.

\section{MATERIAL AND METHODS}

\section{Resistant cell line and its maintenance}

A stable cell line of sainfoin (Onobrychis viciaefolia Scop) resistant to $10 \mathrm{~m} \mathrm{~mol} / \mathrm{L}$ hydroxyproline (HYP)[4] was used as a initial material. Callus cultures of this cell line were subcultured at 3 - 4 week interval on MS medium[5] supplemented with $3 \%$ sucrose, $500 \mathrm{mg} / \mathrm{L}$ casein hydrolysate (CH), $1 \mathrm{mg} / \mathrm{L} 2$, 4-D and $0.5 \mathrm{mg} / \mathrm{L} 6-\mathrm{BA}$.

\section{Protoplast isolation}

Protoplasts were isolated enzymatically from 9-10 d old calli of HYP resistant cell line. Usually $1.5 \mathrm{~g}$ callus was incubated in $10 \mathrm{ml}$ enzyme solution on a shaker $(50 \mathrm{rpm})$ at $25^{\circ} \mathrm{C} \pm 1^{\circ} \mathrm{C}$ for $6 \mathrm{~h}$ in dark. The enzyme solutions used are given in Tab 1 . After digestion, the protoplast suspension was passed through $80 \mu$ m nylon mesh, and $2 \mathrm{X}$ volume of $0.16 \mathrm{~mol} / \mathrm{L} \mathrm{CaCl}_{2} .2 \mathrm{H}_{2} 0$ solution $(\mathrm{PH} 5.8$ 6.2) was added. Protoplasts were collected by centrifugation at $800 \mathrm{rpm}$ for $10 \mathrm{~min}$. The sedimented protoplasts were purified in $18 \%$ sucrose solution by centrifugation for $5 \mathrm{~min}$ at $600 \mathrm{rpm}$. The floating protoplasts were sucked out with a pipette and placed to a new centrifuge tube. After a wash of protoplasts with protoplast culture medium (Tab 2) by centrifugation, they were used for culture.

Tab 1. The effects of different enzyme compositions on protoplast yield and viability*

\begin{tabular}{|c|c|c|c|}
\hline $\begin{array}{l}\text { No. of enzyme } \\
\text { solution }\end{array}$ & Enzyme combination & $\begin{array}{c}\text { Yield of } \\
\text { protoplasts } \\
\text { (cells / g.f.w) }\end{array}$ & $\begin{array}{c}\text { Viability of } \\
\text { protoplasts } \\
(\%)\end{array}$ \\
\hline 1 & $\begin{array}{l}2 \% \text { cellulase (Onozuka } \\
\mathrm{R}-10)+0.8 \% \text { macero- } \\
\text { zyme } \mathrm{R}-10+1 \% \text { hemi- } \\
\text { cellulase(Sigma) }\end{array}$ & $4.63 \times 10^{6}$ & 81.2 \\
\hline 2 & $\begin{array}{l}2 \% \text { cellulase (Onozuka } \\
\mathrm{R}-10)+0.8 \% \text { macero- } \\
\text { zyme } \mathrm{R}-10\end{array}$ & $3.52 \times 10^{6}$ & 75.9 \\
\hline 3 & $\begin{array}{l}1 \% \text { cellulase(Onozuka } \\
\mathrm{R}-10)+0.5 \% \text { pecti- } \\
\text { nase(Serva) }\end{array}$ & $5.14 \times 10^{6}$ & 79.7 \\
\hline 4 & $\begin{array}{l}1 \% \text { cellulase(Onozuka } \\
\mathrm{R}-10)+0.5 \% \text { pecti- } \\
\text { nase(Serva) }+0.2 \% \\
\text { hemicellulase(Sigma) }\end{array}$ & $5.86 \times 10^{6}$ & 85.6 \\
\hline
\end{tabular}

* All enzyme were prepared in the solution composed of $0.45 \mathrm{~mol} / \mathrm{L}$ mannitol and $0.015 \mathrm{~mol} / \mathrm{L} \mathrm{CaCl} 2 \cdot 2 \mathrm{H} 2 \mathrm{O}$, and $\mathrm{pH}$ was adjusted to 5.8-6.2. 


\section{Protoplast culture and callus formation}

The collected protoplast pellets were resuspended in a defined volume of culture medium (Tab 2). The protoplast density was adjusted to about $5 \times 10^{5} / \mathrm{ml}$. Viability of protoplasts was examined by staining with $0.1 \%$ phenosafranin solution(in $0.45 \mathrm{~mol} / \mathrm{L}$ mannitol). $2 \mathrm{ml}$ protoplast suspension solution was dispersed to a Petri dish $\left(6 \mathrm{~cm}\right.$ diameter). The dishes were kept for $48 \mathrm{~h}$ at $4^{\circ} \mathrm{C}$, then moved to the culture chamber at $25^{\circ} \mathrm{C} \pm 1^{\circ} \mathrm{C}$ in dark.

The division frequency of protoplasts was calculated after $8 \mathrm{~d}$ in culture. The plating efficiency was counted at $20 \mathrm{~d}$ of culture.

In order to stimulate sustained divisions and colony formation, freshly prepared medium with reduced osmoticum concentration was added after 10 and $20 \mathrm{~d}$ in culture. The visible colonies (1-2 $\mathrm{mm}$ in size) derived from protoplasts were transferred onto MS medium (Tab 2) to form callus.

Tab 2. Media for protoplast culture and callus formation

\begin{tabular}{llll}
\hline \multirow{2}{*}{$\begin{array}{l}\text { Supplements in } \\
\text { media }\end{array}$} & \multicolumn{3}{c}{ Basal media } \\
\cline { 2 - 4 } & SH[6] & V-KM[7] & MS[5] \\
\hline sucrose(g/L) & 20 & 20 & 30 \\
glucose(g/L) & $81(0.45 \mathrm{~mol} / \mathrm{L})$ & 20 & 0 \\
CH(mg/L) & 200 & 200 & 500 \\
glutamine(mg/L) & 500 & 500 & 0 \\
HYP(mg/L) & 200 & 200 & 0 \\
2, 4-D(mg/L) & 1 & 1 & 1 \\
6-BA(mg/L) & 0 & 0.5 & 0.5 \\
zeatin(mg/L) & 0 & 0.2 & 0 \\
NAA(mg/L) & 0.2 & 0.2 & 0 \\
KT(mg/L) & 0.5 & 0 & 0 \\
agar(\%) & 0 & 0 & 0.7 \\
\hline
\end{tabular}

\section{Plant regeneration}

Proliferating calli (ca. $4 \mathrm{~mm}$ in size) were transferred on MS medium with $3 \%$ sucrose, 500 $\mathrm{mg} / \mathrm{L} \mathrm{CH}, 2 \mathrm{mg} / \mathrm{L} \mathrm{6-BA}$ in combination with $0.2 \mathrm{mg} / \mathrm{L} \mathrm{NAA}$ or IAA to induce shoot differentiation. All cultures for differentiation were incubated at $26^{\circ} \mathrm{C} / 20^{\circ} \mathrm{C}$ day/night) under illumination of 2000 lux fluorescent source $12 \mathrm{~h}$ per day). When shoots grew up to $4-5 \mathrm{~cm}$ high, they were cut and transplanted on MS medium with or without $1 \mathrm{mg} / \mathrm{L}$ IAA to induce roots.

\section{Chromosome count}

Root tips of protoplast-regenerated plants were cut and pretreated for $2 \mathrm{~h}$ in saturated $\mathrm{p}$ dichlorobenzene solution, then washed thoroughly with distilled water for 4-5 times. The pretreated root tips were fixed in a mixture of ethanol and acetic acid (3:1, v/v) for 1-24 h, and hydrolyzed in $1 \mathrm{~N} \mathrm{HCl}$ at $60^{\circ} \mathrm{C}$ for $10-15 \mathrm{~min}$. After rinsing with distilled water, the root tips were stained in $0.5 \%$ haematoxylin solution for $6 \mathrm{~h}$ at room temperature. After squashed, the chromosome numbers were counted under microscope.

\section{Tests of resistance to $\mathrm{HYP}$ and sodium chloride $(\mathrm{NaCl})$}

The protoplast derived calli were transferred on MS medium containing $\mathrm{HYP}$ or $\mathrm{NaCl}$, and cultured for one month to observe their tolerance to $\mathrm{HYP}$ or $\mathrm{NaC} 1.20$ regenerated plants were transferred on MS medium containing $10 \mathrm{~m} \mathrm{~mol} / \mathrm{L} \mathrm{HYP} \mathrm{or} 1.0 \% \mathrm{NaCl}$ to test their resistance. 
Plant regeneration from sainfoin protoplasts

\section{RESULTS AND DISCUSSION}

\section{Isolation and purification of protoplasts}

For protoplast isolation, different enzyme solutions were tested. As shown in Tab 1, a large number of protoplasts could be released from all enzyme solutions used. However, the yields of protoplasts were obviously higher in solution No 3 and No 4 than that in No 1 and No 2. Combinations of cellulase R-10(Yakult co. ltd) and pectinase, such as macerozyme R-10 (Yacult co. ltd) and pectinase(Serva) were suitable to the isolation of O. viciaefolia protoplasts, but pectinase(Serva) was much more effective. Hemicellulase(Sigma) could increase protoplast yield obviously. After purification with $18 \%$ sucrose solution, protoplast yield in solution No 4 was $5.86 \times 10^{6}$ per g.f.w. The rate of viable protoplasts isolated from enzyme No 4 was also relatively higher (over 85\%). Besides, protoplast yields and viability strongly depeneded upon the states of source callus used for protoplast preparation. Only those calli which were in fast growing, i.e., 9 - 10 day old cultures after subculture on fresh medium, could give rise to higher yield and vigorous protoplasts.

The freshly isolated protoplasts were spherical with various size ranged from 15$25 \mu \mathrm{m}$ in diameter (Fig 1 ).

\section{Protoplast culture and callus formation}

Using liquid thin layer culture method and at given conditions as described above, the first division usually occured within 4-5 d of protoplast culture (Fig 2). The second to fourth divisions were followed after $10 \mathrm{~d}$ in culture (Fig 3). Meanwhile, both equal and unequal divisions were observed. Regular dilutions of protoplast cultures by adding fresh liquid medium with reduced osmotic pressure enhanced the growth of cell clusters and colony formation. When $0.5 \mathrm{ml}$ fresh inedium with half stretlgth of osmoticum $(0.225 \mathrm{~mol} / \mathrm{L}$ glucose $)$ was added to the cultures at 10 th day and 20th day of culture, cell clusters and colonies successfully grew (Fig 4). Numerous colonies visible to naked eyes were obtained within one and half month since protoplast inoculation (Fig 5). It was beneficial to improve oxygen condition by shaking the culture dishes twice a day.

When colonies reached to 1-2 $\mathrm{mm}$ in size, they were transferred to agar-solidified MS medium with $\mathrm{lmg} / \mathrm{L} \mathrm{2,} \mathrm{4-D} \mathrm{and} 0.5 \mathrm{mg} / \mathrm{L} \mathrm{6-BA} \mathrm{(as} \mathrm{shown} \mathrm{in} \mathrm{Tab} \mathrm{2)} \mathrm{and}$ subcultured twice at 3 -week interval. This made the colonies proliferate and callus be formed (Fig 6),

The effects of several factors on protoplast culture were compared. Tab 3 indicated the influences of protoplast density and two kinds of basal media on cell division. It was observed that SH medium[6] was apparently preferable to V-KM medium[7] for culturing sainfoin protoplasts. The highest division frequency and plating efficiency were obtained when SH medium was used and the protoplast density was $4.0-5.0 \times 10^{5} / \mathrm{ml}$. As to osmoticum, perfect results were obtained when $0.45 \mathrm{~mol} / \mathrm{L}$ glucose in combination with $2 \%$ sucrose was used as osmotical regulator 
(Tab 4). The results from Tab 4 suggested that no clear difference was observed in cell division frequency whatever glucose or mannitol was used Whereas, the plating efficiency was much higher when using glucose (5.2\%).

Tab 3. Effects of basal medium and protoplast density on protoplast culture

\begin{tabular}{cccc}
\hline Medium* & Protoplast density & $\begin{array}{c}\text { Division } \\
\text { frequency } \\
(\%)\end{array}$ & $\begin{array}{c}\text { Plating } \\
\text { efficiency } \\
(\%)\end{array}$ \\
\hline $\mathrm{SH}[6]$ & $1.0 \times 10^{5} / \mathrm{ml}$ & 8.5 & 2.3 \\
& $2.0 \times 10^{5} / \mathrm{ml}$ & 19.4 & 2.6 \\
& $4.0 \times 10^{5} / \mathrm{ml}$ & 57.1 & 5.7 \\
& $5.0 \times 10^{5} / \mathrm{ml}$ & 60.2 & 4.9 \\
V-KM[7] & $1.0 \times 10^{5} / \mathrm{ml}$ & 3.3 & \\
& $2.0 \times 10^{5} / \mathrm{ml}$ & 17.6 & 3.8 \\
& $4.0 \times 10^{5} / \mathrm{ml}$ & 55.5 & 4.2 \\
& $5.0 \times 10^{5} / \mathrm{ml}$ & 52.8 & 3.4 \\
\hline
\end{tabular}

* All media were supplemented with $2 \%$ sucrose, 0.45 $\mathrm{mol} / \mathrm{L}$ glucose, $200 \mathrm{mg} / \mathrm{L} \mathrm{CH}, 500 \mathrm{mg} / \mathrm{L}$ glutamine, 1 $\mathrm{mg} / \mathrm{L} 2,4-\mathrm{D}, 0.5 \mathrm{mg} / \mathrm{L} \mathrm{KT}$ and $0.2 \mathrm{mg} / \mathrm{L} \mathrm{NAA}$.

Tab 4. Influence of glucose and mannitol as medium(SH) osmoticum to protoplast culture*

\begin{tabular}{cccc}
\hline Osmoticum & $\begin{array}{c}\text { Protoplast } \\
\text { density }\end{array}$ & $\begin{array}{c}\text { Frequency of } \\
\text { cell division } \\
(\%)\end{array}$ & $\begin{array}{c}\text { Plating } \\
\text { efficiency } \\
(\%)\end{array}$ \\
\hline glucose $(0.45 \mathrm{~mol} / \mathrm{L})$ & $5.0 \times 10^{5} / \mathrm{ml}$ & 56.9 & 5.2 \\
mannitol $(0.45 \mathrm{~mol} / \mathrm{L})$ & $5.0 \times 10^{5} / \mathrm{ml}$ & 55.5 & 1.4 \\
\hline
\end{tabular}

* The media were supplemented with the same amount of $\mathrm{CH}$, glutamine, 2, 4-D, KT and NAA as shown in Tab 3. Plating efficiency was the percentage of formed miçrocalli in total protoplasts inoculated.

Some chemical compounds, such as $\mathrm{CH}$, glutamine and HYP exhibited effective results for protoplast culture (Tab 5). It was observed that any of the three compounds used alone resulted in remarkable increase of division frequency and promoting colony formation. However, even higher frequency of division and efficiency of colony formation could be obtained when these three compounds were used in combination (Tab 5). The promotive effect of certain amount HYP to protoplast growth have been reported by other anthors[8]. 
Plant regeneration from sainfoin protoplasts

Tab 5. Influence of $\mathrm{CH}$, glutamine and HYP on sainfoin protoplast culture*

\begin{tabular}{llcc}
\hline $\begin{array}{l}\text { Compounds } \\
\text { added }\end{array}$ & $\begin{array}{l}\text { Concentration } \\
(\mathrm{mg} / \mathrm{L})\end{array}$ & $\begin{array}{c}\text { Frequency of } \\
\text { cell division } \\
(\%)\end{array}$ & $\begin{array}{c}\text { Efficiency } \\
\text { of colony } \\
\text { formation(\%) }\end{array}$ \\
\hline control & 0 & 20.6 & 1.7 \\
CH & 200 & 34.8 & 2.1 \\
glutamine & 500 & 52.2 & 3.4 \\
HYP & 200 & 66.2 & 2.4 \\
CH + gluta- & $200+500+$ & & \\
mine + HYP & 200 & 60.3 & 4.9 \\
\hline
\end{tabular}

"Medium used in this experiment was SH supplemented with $2 \%$ sucrose, $0.45 \mathrm{~mol} / \mathrm{L}$ glucose, $1 \mathrm{mg} / \mathrm{L} 2,4-\mathrm{D}, 0.5$ $\mathrm{mg} / \mathrm{L} \mathrm{KT}$ and $0.2 \mathrm{mg} / \mathrm{L} \mathrm{NAA}$.

\section{Plant regeneration}

For shoot induction from protocalli, several constitutive media with various phytohormone combinations were tested. The most frequent bud differentiation was observed on MS medium with $3 \%$ sucrose, $500 \mathrm{mg} / \mathrm{L} \mathrm{CH}, 2 \mathrm{mg} / \mathrm{L} 6-\mathrm{BA}$ and 0.2 $\mathrm{mg} / \mathrm{L}$ NAA or IAA. With this medium almost all protocalli differentiated into green buds one month after transfer. However these buds developed rather slowly. To improve shoot growth, different concentrations of gibberelic acid $\left(\mathrm{GA}_{3}\right)$ were added in the medium. As given in Tab $6,0.2-0.5 \mathrm{mg} / \mathrm{L} \mathrm{GA}_{3}$ played a promotive role in shoot elongation. When differentiated buds together with linked calli were transferred on the medium containing $0.2-0.5 \mathrm{mg} / \mathrm{L} \mathrm{GA}_{3}$, numerous shoots elongated in 3-4 weeks. When shoots grew up to over $4 \mathrm{~cm}$, they were transplanted to root induction medium, i.e. MS medium with $1 \mathrm{mg} / \mathrm{L}$ IAA or without any auxin. Three weeks later, plantlets with roots were produced (Fig 7).

Tab 6. The effects of $\mathrm{GA}_{3}$ concentration on shoot elongation*

\begin{tabular}{cl}
\hline $\mathrm{GA}_{3}(\mathrm{mg} / \mathrm{L})$ & Shoot elongation $^{* *}$ \\
\hline 0 & - \\
0.1 & + \\
0.2 & +++ \\
0.5 & ++++ \\
1.0 & ++ \\
1.5 & - \\
2.0 & - \\
3.0 & - \\
\hline
\end{tabular}

* Basal medium used in this experiment was MS medium with $3 \%$ sucrose, $500 \mathrm{mg} / \mathrm{L} \mathrm{CH}, 2 \mathrm{mg} / \mathrm{L} 6-\mathrm{BA}$ and 0.2 mg/L NAA.

${ }^{* *}-$, noneffective; + , a little positive result; ++ , apparent positive result; +++ , remarkable promotive effect; ++ ++ , strong promotive result. 


\section{Chromosome number}

10 regenerated plants were examined fot chromosome number. It was revealed that all checked plants had normal chromosome number, i.e., $2 \mathrm{n}=28$ (Fig 8).

\section{Resistance of protocalli and regenerated plants to $\mathrm{HYP}$ or $\mathrm{NaCl}$}

Protoplast-derived calli could grow well on the inedium containing $10 \mathrm{mmol} / \mathrm{L}$ HYP, and expressed a certain tolerance to $0.8 \% \mathrm{NaCl}$ (Tab 7). The growth rate in the presence of $10 \mathrm{mmol} / \mathrm{L} \mathrm{HYP}$ in the mediuln corresponded to $78 \%$ of the control.

Tab 7. Resistance of protoplast-derived calli to $\mathrm{HYP}$ and $\mathrm{NaCl}^{*}$

\begin{tabular}{llcc}
\hline Stress factor & Concentration & \multicolumn{2}{c}{ Rate of relative growth (\%) } \\
\cline { 3 - 4 } & & HYP-resistance & Wild type \\
\hline $\mathrm{CK}$ & 0 & 100 & 100 \\
$\mathrm{HYP}$ & $10 \mathrm{mmol} / \mathrm{L}$ & 78 & 0 \\
$\mathrm{NaCl}$ & $0.8 \%$ & 56 & 0 \\
\hline
\end{tabular}

* Basal medium used was the same as MS shown in Tab 2.

All 20 regenerated plants tested could grow normally on the medium containing $10 \mathrm{mmol} / \mathrm{L} \mathrm{HYP}$ or $1.0 \% \mathrm{NaCl}$. However, the regenerated plants from control calli, i.e. its wild type, could not grow on MS medium containing $5 \mathrm{mmol} / \mathrm{L} \mathrm{HYP}$ or $0.8 \%$ $\mathrm{NaCl}$. This indicated that the tolerance of the resistant cell line to HYP was still retained after long term protoplast culture. Resistance test of seedling couhl not be made since the seeds have not yet been obtained from protoplast-regenerated plants.

The protoplast culture system of this investigation would be useful to study somatic hybridization. The protoplast fusion between this cell line and alfalfa has been undertaking in our laboratory.

\section{ACKNOWLEDGEMENT}

This work was supported by National Natural Science Foundation of China.

\section{REFERENCES}

[1] Cocking EC. Applications of protoplast technology to agriculture, In : Lecture Proceedings 6th International Symposium. Basel 1983: pp 123-6.

[2] Jia.JF, Wu NF, Shi YJ , zhang Q. Plant regeneration from callus protoplasts of sainfoin (Onobrychis viciaefolia). Acta Biol Exp Sinica 1989; 22(3):353-7.

[3] Pupilli F, Damiani F, Pezzotti M, Arcioni S. Plant regeneration from callus protoplasts of Onobrychis viciaefolia Scop (sainfoin). Plant Sci 1989; 63:87-94.

[4] Zhao XS, Jia ,JF. Selection and characterization of cultured sainfoin (Onobrychis viciaefolia Stop) callus resistant to hydroxyproline. Acta Biol Exp Sinica 1993; 26(3):275-9. 


\section{Plant regeneration from sainfoin protoplasts}

[5] Murashige. T, Skoog F. Revised media for rapid growth and bioassays with tobacco tissue culture. Physiol Plant 1962; 15:473-9.

[6] Schenk RU, Hildebrandt AC. Medium and techniques for induction and growth of monocotyledonous and dicotyledonous cell cultures. Can J Bot 1972; 50:199-204.

[7] Binding H, Nehls R, Koek R, Finger J, Mordhorst G. Comparative studies of the dicotyledoneae. class. Z. Pflanzenphysiol 1981; 101:119-30.

[8] Liu SQ, Cai QQ. Callus formation from protoplasts and plant regeneration of tissue culture of Silybum marianum Gaerth. Acta Botanica Sinica 1990; 32(1):19-25.

Received 30-8-1994. Revised 27-4-1995. Accepted 25-7-1995

$\triangleright$ Fig 1. Protoplasts isolated from calli of sainfoin, $x 400$.

Fig 2. First division after $5 \mathrm{~d}$ in culture used $\mathrm{SH}$ mediuin, $\times 600$

Fig 3. A small cluster after $8 \mathrm{~d}$ in protoplast culture used SH medium, $\times 300$

Fig 4. A cell colony formed from a protoplast, $\times 150$.

Fig 5. Protoplast-derived calli forined in liquid medium after 6 weeks in culture.

Fig 6. Proliferating calli formed on ag/ar-solidified MS medium with $1 \mathrm{mg} / \mathrm{L} \mathrm{2,} \mathrm{4-D} \mathrm{and}$ $0.5 \mathrm{mg} / \mathrm{L} 6$-BA.

Fig 7. Plantlets regenerated from protocalli.

Fig 8. Chromosome set from root tip of protoplast-derived plants $(2 \mathrm{n}=28)$. 
Xu ZQ and JF Jia

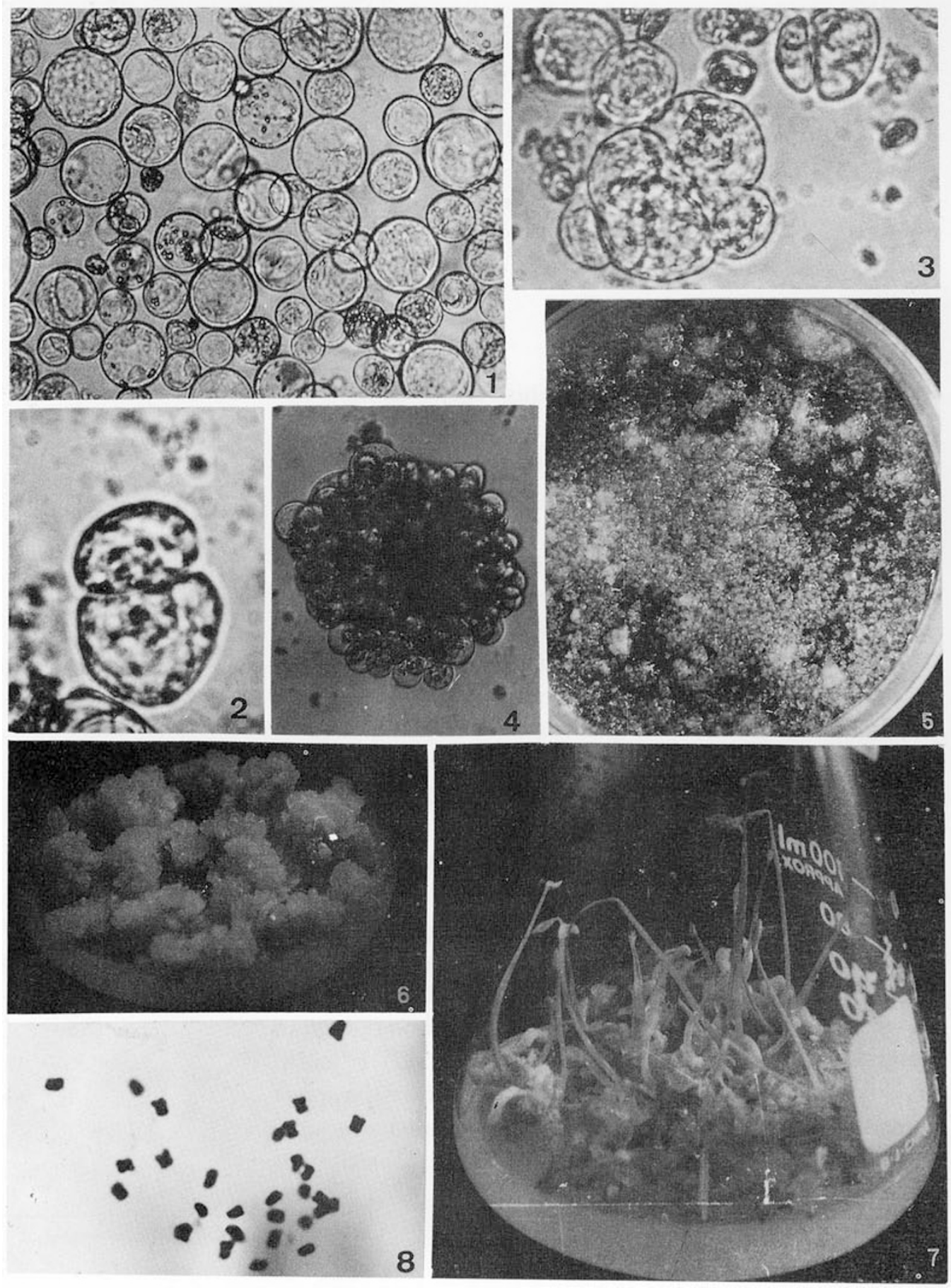

